\title{
Intervensi CBIA untuk Meningkatkan Pengetahuan, Sikap, dan Perilaku Penggunaan Antibiotik yang Rasional pada Anggota Bina Keluarga Balita
}

\section{CBIA Intervention to Enhance Community Development of Knowledge, Attitudes, and Behavior of Antibiotic's Rational Use against Members of the Toddler's Family}

\author{
Arfian Bela $M^{1}$, Sri Suryawati $i^{2}$ Rustamaji ${ }^{2}$ \\ ${ }^{1}$ PT Kimia Farma-RSUP Dr. Sardjito Yogyakarta \\ ${ }^{2}$ Departemen Farmakologi dan Terapi Fakultas Kedokteran Universitas Gadjah Mada Yogyakarta
}

\begin{abstract}
ABSTRAK
Antibiotika sering diresepkan untuk pasien anak. Penggunaan antibiotik yang salah pada anak sering kali terkait dengan cara penggunaan yang tidak rasional. Untuk mengantisipasi hal tersebut, diperlukan peningkatan pengetahuan, sikap, dan perilaku orang tua. Program BKB (Bina Keluarga Balita) merupakan gerakan bersama antara pemerintah dan masyarakat dengan ibu sebagai sasaran utama yang kaitannya dengan hantaran tumbuh kembang anak. Dengan demikian kerjasama kegiatan meningkatkan pengetahuan orang tua dalam menggunakan antibiotik dengan benar pada BKB akan sangat bermanfaat. Tujuan penelitian adalah untuk meningkatkan pengetahuan, sikap, dan perilaku penggunaan antibiotik yang rasional pada anggota BKB di desa Banguntapan. Penelitian ini menggunakan pendekatan CBIA (Cara Belajar Ibu Aktif). CBIA yang dilakukan berupa pemberian penyuluhan, modul, dan diskusi kelompok kecil pada anggotan BKB. Paramater utama penelitian diukur dengan menggunakan kuesioner untuk mengetahui peningkatan pengetahuan, sikap dan perilaku setelah mengikuti kegiatan. Anggota BKB dibagi menjadi 2 kelompok yakni kelompok intervensi dan kontrol. Pengamatan dilakukan pada sebelum dan sesudah kegiatan serta pada minggu ke-3 setelah kegiatan. Hasil penelitian menunjukkan bahwa Intervensi CBIA pada ibu-ibu kelompok BKB meningkatkan pengetahuan, sikap, dan perilaku penggunaan antibiotik yang rasional. Pada kelompok kontrol tidak ada kenaikan antara pretest-postest-1 dan posttest-2. Terjadi peningkatan pengetahuan, sikap, dan perilaku anggota BKB secara bermakna pada kelompok intervensi $(P<0,05)$.
\end{abstract}

Kata Kunci: Antibiotik, CBIA, pengetahuan, perilaku, sikap

\begin{abstract}
Antibiotics are frequently prescribed for pediatric patients. The misuse of antibiotics in children is often associated with the use of an irrational manner. To anticipate this matter, the required increase in knowledge, attitudes, and behaviors of parents. BKB Programme is a joint motion between the government and the public with the mother as the main target which is associated with the delivery of child development. Thereby increasing the knowledge of parents of cooperation in using antibiotics correctly at members of $B K B$ will be very useful. The aim of this study was to improve knowledge, attitudes, and behavior of rational use of antibiotics in members of BKB in Banguntapan village. This study uses CBIA (Mother Active Learning Method) approach. CBIA conducted the form of counseling, modules, and small group discussions on BKB members. The main parameter of the study was measured using a questionnaire to determine the increase of knowledge, attitudes and behavior after participating in the activities. BKB members divided into two groups, namely the intervention and control groups. Observations were made before and after the activities as well as on the 3rd week after activity. The results showed that CBIA intervention improved knowledge, attitudes, and behavior of rational use of antibiotics. In control group there was no increase in the pretest-posttest 1 and posttest 2. An increase of in knowledge, attitudes, and behavior of members of $B K B$ significantly in the intervention group $(P<0,05)$.
\end{abstract}

Keywords: Antibiotics, attitude, behavior, CBIA, knowledge

Korespondensi: Arfian Bela M. PT Kimia Farma RSUP Dr. Sardjito Yogyakarta Tel. (0274) 489184 Email: arfianbela@gmail.com 


\section{PENDAHULUAN}

Antibiotik merupakan golongan obat yang digunakan untuk penanganan pasien yang terbukti atau diduga mengalami infeksi bakteri. Penggunaan antibiotik yang tidak sesuai indikasi akan menyebabkan resistensi obat. Resistensi antibiotik (antibiotic resistency) merupakan kemampuan bakteri atau kuman lainnya untuk melakukan perlawanan terhadap pengaruh antibiotik (1). Strategi yang efektif untuk pencegahan resistensi antibiotik dalam unit perawatan intensif yang tersedia dan harus dilaksanakan secara sungguh-sungguh (2). Resistensi antibiotik dapat dikurangi dengan menggunakan antibiotik secara hati-hati berdasarkan pedoman penggunaan antibiotik dan mempertimbangkan berbagai data seperti farmakokinetik dan farmakodinamik sifat antibiotik, tes diagnostik, uji kepekaan antimikroba, respon klinis, dan efek pada mikrobiota, serta oleh perkembangan antibiotik baru (3). Penggunaan antibiotik yang salah (misuse) kepada anak-anak sering kali terkait dengan cara penggunaan antibiotik yang tidak rasional. Untuk mengatasi penggunaan antibiotik yang tidak rasional maka peningkatan pengetahuan, sikap, dan perilaku orang tua tentang penggunaan antibiotik sangat diperlukan.

Program Bina Keluarga Balita (BKB) merupakan gerakan bersama antara pemerintah dan masyarakat dengan ibu sebagai sasaran utama yang kaitannya dengan hantaran tumbuh kembang anak, deteksi dini kelainan atau kecacatan dan akhirnya menyiapkan anak balitanya siap sekolah bersama anak-anak lain (4). Keberadaan BKB dapat dieksplorasi dalam rangka peningkatan pengetahuan, sikap, dan perilaku khususnya mengenai penggunaan antibiotika yang rasional pada Balita. Salah satu wilayah di Propinsi DI Yogyakarta yang menerapkan BKB adalah Kecamatan Banguntapan, Kabupaten Bantul.

Cara Belajar Ibu Aktif (CBIA) merupakan metode pendidikan masyarakat yang orientasinya pada peran aktif peserta didik dalam mencari informasi, menumbuhkan sikap, dan mengubah perilaku. Metode intervensi ini berdasarkan pada proses belajar mandiri, yaitu terdiri dari fasilitator, narasumber dan para peserta(5).

Berdasarkan fakta di atas timbul permasalahan yang menarik untuk dikaji apakah intervensi menggunakan metode CBIA dapat meningkatkan pengetahuan, sikap, dan perilaku anggota BKB tentang penggunaan antibiotik yang rasional? Penelitian ini bertujuan untuk meningkatkan pengetahuan, sikap, dan perilaku penggunaan antibiotik yang rasional pada anggota Bina Keluarga Balita di desa Banguntapan.

\section{METODE}

Penelitian ini merupakan penelitian eksperimental semu menggunakan rancangan pre test-post test control group design. Responden adalah ibu-ibu kelompok Bina Keluarga Balita (BKB) diintervensi dengan metode CBIA disertai dengan umpan balik secara tertulis ataupun lisan.

Perlakukan dengan metode CBIA dilakukan dengan diawali pemberian lembar kuesioner pretest dilanjutkan penyampaian materi tentang antibiotik oleh nara sumber, kemudian dilakukan diskusi kelompok kecil ibu-ibu BKB. Setiap kelompok didampingi oleh fasilitator dan dilengkapi dengan bacaan materi antibiotik secara luas baik dari macam, senyawa aktif, indikasi, penggunaan, efek samping, resistensi, pembelian dengan resep, dan cara atau aturan pemakaian yang benar. Hasil diskusi kelompok kecil dipaparkan pada kelompok besar yang didampingi oleh nara sumber. Pada kesempatan tersebut para ibu dapat mengajukan pendapat dan pertanyaan kepada nara sumber seputar materi. Kegiatan diakhiri dengan pengisian posttest ke-1 serta diumumkan kepada responden untuk hadir tiga minggu kemudian untuk mengisi posttest ke- 2 .

Pada penelitian ini subjek/responden terdiri dari kelompok kontrol dan kelompok perlakuan. Kelompok kontrol yaitu ibu-ibu anggota BKB berjumlah 41 orang dari wilayah pedukuhan Karangbendo, Banguntapan, sedangkan kelompok perlakuan juga ibu-ibu anggota BKB berjumlah 40 orang dari wilayah pedukuhan Jaranan, Banguntapan, Bantul. Responden berdomisili di masingmasing pedukuhan, kalurahan Banguntapan, mampu membaca, menulis serta bersedia mengikuti proses penelitian dari awal hingga berakhirnya penelitian. Pada kelompok kontrol tidak dilakukan intervensi CBIA, hanya dilakukan pre test pada minggu pertama dan post test pada minggu ketiga sesudah pemberian materi dengan metode ceramah oleh narasumber.

Pengukuran pengetahuan, sikap dan perilaku responden dilakukan dengan pemberian kuesioner. Untuk mengukur tingkat pengetahuan tentang antibiotik secara umum, digunakan skala dikotomi dengan skor 1 kalau benar dan 0 kalau salah. Untuk mengukur sikap menggunakan skala Likert (5 skala) yaitu sangat setuju (SS), setuju (S), ragu (RG), tidak setuju (TS), sangat tidak setuju (STS). Beberapa pertanyaan yang bersifat positif SS (skor 5), S (4), RG (3), TS (2), STS (1), sedangkan pertanyaan tidak setuju skore diberikan sebaliknya. Pengukuran perilaku dilakukan berdasarkan jawaban responden terhadap essay atau studi kasus, apabila dapat menjawab dengan tepat dan benar diberi skor 1, jika salah atau kurang skor 0 . Pengukuran data dilakukan sebelum dan sesudah intervensi dengan cara prospektif.

Data penelitian yang terkumpul disajikan secara deskriptif untuk mengetahui adanya perbedaan hasil pengetahuan, sikap, dan perilaku responden sebelum dan sesudah diintervensi dengan CBIA dalam bentuk tabel dan narasi. Untuk mengetahui hubungan antara kelompok kontrol dan perlakuan dengan tingkat pengetahuan, sikap, dan perilaku dengan analisis perbedaan skor sebelum dan sesudah intervensi CBIA. Analisis hubungan antara pengetahuan, sikap dan perilaku dalam satu kelompok menggunakan analisis perbedaan kelompok (uji Mann Whitney).

\section{HASIL}

Hasil penelitian terhadap 81 responden dari kelompok perlakuan dan kelompok kontrol berdasarkan umur, tingkat pendidikan, dan pekerjaan dapat dilihat pada Tabel 1. Hasil menunjukkan bahwa mayoritas responden (42\%) berusia antara 41-50 tahun. Tingkat pendidikan responden yang paling dominan pada tingkat SLTA sederajat sebesar $45 \%$, sedangkan pekerjaan responden terbesar adalah Ibu Rumah Tangga (IRT) sebesar 52\%. 
Tabel 1. Ciri-ciri subjek penelitian berdasarkan umur, tingkat pendidikan, dan pekerjaan

\begin{tabular}{llcc}
\hline \multicolumn{2}{c}{ Variabel } & Frekuensi & Presentase \\
\cline { 3 - 4 } Umur (N=81) & 20-30 Tahun & 18 & 23 \\
& $31-40$ Tahun & 19 & 23 \\
& $41-50$ Tahun & 34 & 42 \\
& > 50 Tahun & 10 & 12 \\
Pendidikan (N=81) & SD & 10 & 12 \\
& SLTP & 28 & 35 \\
& SLTA Sederajat & 37 & 45 \\
& Diploma (D3) & 4 & 5 \\
& Sarjana (S1) & 2 & 3 \\
& & & \\
Pekerjaan (N=81) & IRT & 42 & 52 \\
& Wiraswasta & 19 & 22 \\
& Swasta & 10 & 12 \\
& PNS & 2 & 3 \\
& Kader & 4 & 5 \\
& Pedagang & 2 & 3 \\
& Buruh & 2 & 3 \\
\hline
\end{tabular}

Hasil analisis menunjukkan pada kelompok perlakuan terdapat perbaikan pengetahuan, sikap dan perilaku yang terus meningkat hingga minggu ketiga. Secara deskriptif data menunjukkan pada kelompok kontrol tidak terdapat peningkatan yang berarti. Hasil uji statistik menunjukkan terdapat perbedaan signifikan pengetahuan sikap dan perilaku responden sesudah perlakukan antara kedua kelompok perlakuan dan kontrol.

\section{DISKUSI}

\section{Karakteristik Subjek Penelitian}

Nilai persentase usia responden paling tinggi antara usia 41-50 tahun yang tersaji pada Tabel 1 tersebut disebabkan karena responden bukan hanya ibu dari balita, akan tetapi ada juga yang hadir pengasuhnya bahkan neneknya yang juga tergabung dan rajin hadir pada kegiatan BKB. Tingkat pendidikan yang paling dominan adalah tingkat SLTA, sedang pekerjaan responden yang banyak IRT, hal ini dapat difahami karena sebagian anggota BKB adalah Ibu Rumah tangga bahkan yang bekerja sebagai pengasuh anak pun menuliskan IRT.

Dampak Metode CBIA terhadap Tingkat Pengetahuan, Sikap, dan Perilaku Ibu BKB

Tingkat pengetahuan, sikap dan perilaku Ibu-ibu kelompok BKB di desa Banguntapan tentang penggunaan antibiotik yang rasional sebelum intervensi (pretest) dan sesudah intervensi CBIA (posttest ke-1) terdapat peningkatan skor absolutnya. Jika dilihat dari hasil tersebut terdapat kenaikan baik tingkat pengetahuan, sikap dan perilaku. Hal ini disebabkan karena pretest diadakan sebelum adanya intervensi CBIA, sehingga responden hanya mengisi kuesioner tentang antibiotik sesuai dengan kemampuan berfikir dan pengalaman masing-masing. Sesaat setelah diberikan intervensi, berupa pemberian modul, penyuluhan, dilanjutkan dengan diskusi, sehingga pada waktu pemberian posttest ke-1 dengan soal yang sama dengan pretest ternyata hasilnya ada kenaikan. Pengetahuan (knowledge) adalah hasil yang didapatkan dari informasi dan kemudian dimengerti, diperhatikan dan dapat diingat. Berbagai macam bentuknya baik berupa pendidikan formal dan sumber non formal dapat berupa percakapan sehari-hari, menonton acara televisi, ataupun berasal dari pengalaman hidup yang lainnya (7).

Widayati dalam penelitiannya terhadap 31 siswi kelas VII satu SMP telah menstruasi yang diambil dengan teknik proportional random sampling menyimpulkan bahwa tingkat pengetahuan responden sesudah pendidikan sebaya $(77,4 \%)$ lebih tinggi secara signifikan $(Z=4,82)$ dibandingkan sebelum intervensi (67,7\%) (8). Hasil penelitian tersebut memperkuat hasil penelitian ini bahwa setelah diadakan pendidikan tentang masalah menstruasi ternyata tingkat pengetahuan siswa meningkat dibandingkan dengan sebelum pendidikan. Penelitian awal yang membahas tingkat pengetahuan tentang antibiotik terhadap 625 responden di Kota Yogyakarta juga menemukan bahwa mereka yang mempunyai tingkat pengetahuan baik tentang antibiotik, memiliki keyakinan yang tepat pula tentang penggunaan antibiotik, sedangkan yang mempunyai pengetahuan sedang, akan memiliki keyakinan yang rendah, sehingga disarankan untuk diadakan intervensi penggunaan antibiotik di masyarakat (9).

Penelitian ini membuktikan bahwa perilaku responden cenderung membaik setelah adanya perlakuan CBIA. Suatu studi dengan menggunakan 559 sampel masyarakat di Yogyakarta menemukan bahwa 52\% masyarakat Yogyakarta menggunakan antibiotik untuk pengobatan sendiri. Mengingat hasil penelitian tersebut, maka faktor yang mempengaruhi niat seseorang untuk mengobati sendiri dengan antibiotik harus diselidiki untuk memahami perilaku seseorang (10). Studi lain juga mencerminkan bahwa pengetahuan seseorang ada hubungannya dengan perilaku seperti yang didapatkan dari penelitian ini (11). Penelitian sejenis tentang perilaku dilakukan terhadap 134 orang pasien yang telah dirawat lebih dari 2 hari di ruang Dahlia II pada RSUD X selama bulan Juni 2014, menyimpulkan bahwa perilaku komunikasi petugas memiliki hubungan dengan persepsi sehat-sakit pasien. Faktor lain yang diduga berpengaruh terhadap persepsi sehat-sakit adalah karakteristik pasien yang pada penelitian ini mayoritas pasien memiliki pendidikan rendah, dan sosial ekonomi kurang (12).

Penelitian terhadap 2500 mahasiswa dari 3 universitas (salah satu universitas kedokteran) di Timur Laut Cina tentang pengetahuan, sikap dan praktek siswa terhadap penggunaan antibiotik, menemukan bahwa kurikulum

Tabel 2. Dampak intervensi pada tingkat Pengetahuan, Sikap dan Perilaku subjek sebelum dan setelah intervensi CBIA

\begin{tabular}{lrrrrr}
\hline \multirow{2}{*}{ Intervensi } & \multicolumn{3}{c}{ Kelompok Perlakuan (N=40) } & \multicolumn{2}{c}{ Kelompok Kontrol (N = 41) } \\
\cline { 2 - 6 } & Pretest & Posttest $k e-1$ & Posttest ke-2 & Pretest & Posttest ke-1 \\
\hline Pengetahuan & 5,95 & 7,475 & 9,00 & 7,56 & 7,07 \\
Sikap & 32,90 & 36,675 & 46,57 & 36,07 & $3,00(\mathrm{p}=0,043)$ \\
Perilaku & 5,825 & 8,00 & 10,00 & 5,66 & $34,70(\mathrm{p}=0,019)$ \\
\hline
\end{tabular}

Sumber: primer (6) 
secara signifikan meningkatkan pengetahuan siswa tentang antibiotik dan resistensi antibiotik yang mungkin timbul dari penggunaan sembarangan (13). Konsep kurikulum pada tiga universitas di Timur Laut Cina tersebut sangat mirip dengan konsep dasar CBIA yaitu metode pembelajaran berdasarkan aktivitas masingmasing responden.

Uji statistik menunjukkan semua unsur baik pengetahuan, sikap dan perilaku terdapat peningkatan yang signifikan. Kenaikan ketiga unsur tersebut dapat disebabkan karena responden setelah diberikan penyuluhan, pemberian modul dan diskusi, evaluasi selanjutnya baru diadakan pada minggu ke-3. Oleh karena itu responden sudah mempelajari bahkan sudah mempraktekkan ilmu yang mereka peroleh dari pertemuan pertama. Kalau dilihat dari peningkatan yang cukup signifikan jika diolah berdasarkan statistik, maka dapat dikatakan bahwa intervensi CBIA sangat efektif untuk komunitas ibu-ibu yang tergabung dalam kelompok BKB. Edukasi dengan dengan cara penyuluhan, diskusi, dan pemberian leaflet obat-obatan, sangat efektif dalam meningkatkan pengetahuan, sikap dan perilaku guru tentang obatobatan yang diperlukan (19). Hal ini sesuai teori yang menyatakan bahwa metode CBIA dapat terbukti efektif untuk meningkatkan pengetahuan dan ketrampilan para ibu peserta dalam pemilihan obat, dan dapat meningkatkan efisiensi penggunaan obat dalam rumah tangga dan kegiatannya disukai oleh para peserta (15). Penelitian lain pada penderita Diabetes Melitus tipe 2 mendukung bahwa CBIA merupakan metode yang efektif untuk meningkatkan pengetahuan dan sikap perilaku pasien terhadap perawatan diri penderita (16). Studi lain yang menggunakan metode CBIA pada penggunaan antibiotik dan tatalaksana Diare juga mendukung efektifitas metode CBIA $(20,21)$

\section{DAFTAR PUSTAKA}

1. Tenover FC. Mechanisms of Antimicrobial Resistance in Bacteria. American Journal of Infection Control. 2006; 34(5): 3-10.

2. Kollef MH. Bench-To-Bedside Review: Antimicrobial Utilization Strategies Aimed at Preventing the Emergence of Bacterial Resistance in The Intensive Care Unit. Critical Care. 2005; 9(5): 459-464.

3. Lee CR, Cho HI, Jeong BC, and Lee SH. Strategies to Minimize Antibiotic Resistance. International Journal of Environmental Research and Public Health. 2013; 10(9): 4274-4305.

4. Badan Kependudukan dan Keluarga Berencana Nasional. Buku Pegangan Kader BKB yang Disempurnakan Usia 0-5 Tahun. Yogyakarta: BKKBN; 2007.

5. Suryawati S. Petunjuk Kegiatan "Meningkatkan Pengetahuan dan Ketrampilan Memilih Obat dengan Metode CBIA". Yogyakarta: Pusat Study Farmakologi Klinik dan Kebijakan Obat Universitas Gadjah Mada; 2009.

6. Mahardika MAB. Intervensi CBIA terhadap Anggota Bina Keluarga Balita untuk Meningkatkan Pengetahuan, Sikap, dan Perilaku Penggunaan Antibiotik yang Rasional. [Tesis]. Fakultas Kedokteran
Peningkatan pengetahuan pasien tentang penggunaan antibiotik penting dilakukan mengingat tingginya pola peresepan antibiotik yang tidak rasiona oleh provider kesehatan. Studi di Yordania menunjukkan masih tingginya penggunaan antibiotik yang tidak rasional bahkan $>50 \%$ dokternya secara rutin meresepkan antibiotik untuk mengobati gejala flu biasa (18). Studi pada mahasiswa kedokteran dan dokter di Rumah Sakit Kisangani menunjukkan skor pengetahuan tentang antibiotik masih tergolong rendah (rata-rata skor $4,9 / 8$ poin), sedangkan skor keyakinan peresepan tentang antibiotik tergolong tinggi $(88,6 \%)$. Peresepan antibiotik yang tinggi tidak diimbangi dengan pengetahuan prescriber yang baik sehingga berdampak pada penggunaan antibiotik yang tidak rasional (22).

Penelitian ini membuktikan bahwa edukasi pada ibu-ibu BKB dengan metode CBIA terbukti dapat meningkatkan pengetahuan sikap dan perilaku penggunaan antibiotik dibandingkan metode ceramah saja. Keuntungan dari metode CBIA ini adalah melatih ibu-ibu BKB untuk berkreasi dengan cara belajar mandiri dirumah setelah dilakukan diskusi dan pemberian bacaan. Metode CBIA dapat terbukti efektif untuk meningkatkan pengetahuan dan ketrampilan ibu dalam pemilihan obat (15). Pendidikan berkelanjutan pada masyarakat perlu dilakukan untuk mengendalikan penggunaan antibiotika yang tidak rasional melalui peran aktif masyarakat.

\section{UCAPAN TERIMAKASIH}

Penulis mengucapkan terima kasih kepada Lurah Desa dan Ketua Tim Penggerak PKK Desa Banguntapan, Kabupaten Bantul atas ljin lokasi penelitian. Terima kasih kepada seluruh Responden anggota BKB Banguntapan, Bantul yang telah bersedia mengikuti penelitian ini dari awal hingga selesai.

Universitas Gadjah Mada, Yogyakarta. 2014.

7. Morton SBG, Greene WH, and Gotlieb NH. Introduction to Health Education and Health Promotion. 2nd edition. Illinois: Waveland Press Inc; 1995.

8. Amelia CR. Pendidikan Sebaya Meningkatkan Pengetahuan Sindrom Pramenstruasi pada Remaja. Jurnal Kedokteran Brawijaya. 2014; 28(2): 152-154.

9. Widayati A, Suryawati S, Charlotte de Crespigny, Hiller JE. Knowledge and Beliefs about Antibiotics among People in Yogyakarta City Indonesia: A Cross Sectional Population-Based Survey. Antimicrobial Resistance and Infection Control. 2012; 1(1): 38.

10. Widayati A, Suryawati S, de Crespigny C, and Hiller JE. Self Medication with Antibiotics in Yogyakarta City Indonesia: A Cross Sectional Population-Based Survey. BMC Research Notes. 2011; 4: 491.

11. Hedin K, Andre M, Håkansson A, Mölstad S, Rodhe N, and Petersson C. A Population-Based Study of Different Antibiotic Prescribing In Different Areas. The British Journal of General Practice. 2006; 56(530): 680-685

12. Nofiyanto E, Andarini S, and Koeswo M. Perilaku Komunikasi Petugas Berhubungan dengan Persepsi Sehat-Sakit Pasien Rawat Inap. Jurnal Kedokteran Brawijaya. 2015; 28(4): 354-358. 
13. Huang $\mathrm{Y}, \mathrm{Gu} J$, Zhang $\mathrm{M}$, et al. Knowledge, Attitude and Practice of Antibiotics: A Questionnaire Study among 2500 Chinese Students. BMC Medical Education. 2013; 13: 163

14. Lestari EIW, Al Rasyid H, dan Thoyib A. Pengaruh Pengetahuan, Sikap, dan Perilaku Perawat tentang Flebotomi terhadap Kualitas Spesimen Laboratorium. Jurnal Kedokteran Brawijaya. 2015; 28(3): 258-262.

15. Suryawati S. CBIA: Improving the Quality of Self Medication through Mothers Active Learning. In: World Health Organization (Ed). Essensial Drugs Monitor No. 32. Geneva: World Health Organization; 2003.

16. Hartayu TS, Mi MI, and Suryawati S. Improving of Type 2 Diabetic Patients' Knowledge, Attitude and Practice Towards Diabetes Self-care by Implementing Community-Based Interactive Approach-Diabetes Mellitus Strategy. BMC Research Notes. 2012; 5: 315320.

17. Azevedo MM, Pinheiro C, Yaphe J, and Baltazar F. Assessing the Impact of a School Intervention to Promote Students' Knowledge and Practices on Correct Antibiotic Use. International Journal of Environmental Research and Public Health. 2013;
10(7): 2920-2931.

18. Shehadeh M, Suaifan G, Darwish RM, Wazaify M, Zaru L, and Alja'fari S. Knowledge, Attitudes and Behavior Regarding Antibiotics Use and Misuse among Adults in the Community of Jordan. A Pilot Study. Saudi Pharmaceutical Journal. 2012; 20(3): 125-133

19. Jha N, Bajracharya O, and Shankar PR. Knowledge, Attitude and Practice towards Medicines among School Teachers in Lalitpur District, Nepal before and After an Educational Intervention. BioMed Central Public Health. 2013; 13: 652-662.

20. Rossetyowati DA. Meningkatkan Pengetahuan, Sikap, dan Perilaku Penggunaan Antibiotika dengan Metode Cara Belajar Ibu Aktif (CBIA) di Kabupaten Jember. [Tesis]. Universitas Gadjah Mada, Yogyakarta. 2012.

21. Kumala AP. CBIA Diare Untuk Meningkatkan Pengetahuan, Sikap dan Perilaku Ibu dalam Tatalaksana Diare pada Balita di Bina Keluaga Balita (BKB) Desa Banguntapan Kabupaten Bantul. [Tesis]. Universitas Gadjah Mada, Yogyakarta. 2014.

22. Thriemer K, Katuala $\mathrm{Y}$, Batoko B, et al. Antibiotic Prescribing in DR Congo: A Knowledge, Attitude and Practice Survey among Medical Doctors and Students. PLoS One. 2013; 8(2): e55495. 